\title{
Determination of the 100-Year Flood Plain on Fourmile Branch at the Savannah River Site, South Carolina, 1996
}

By TIMOTHY H. LANIER

U.S. GEOLOGICAL SURVEY

Water-Resources Investigations Report 96-4271

Prepared in cooperation with the U.S. DEPARTMENT OF ENERGY

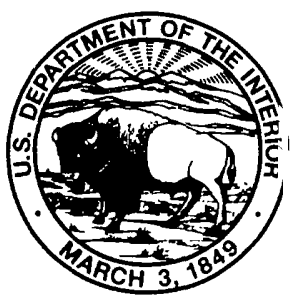




\section{U.S. DEPARTMENT OF THE INTERIOR \\ BRUCE BABBITT, Secretary}

\section{U.S. GEOLOGICAL SURVEY}

Gordon P. Eaton, Director

The use of firm, trade, and brand names in this report is for identification purposes only and does not constitute endorsement by the U.S. Government.

For additional information write to:

Copies of this report can be purchased from:

District Chief

U.S. Geological Survey

Stephenson Center-Suite 129

720 Gracern Road

Columbia, SC 29210-7651
U.S. Geological Survey

Branch of Information Services Box 25286

Denver, CO 80225-0286 


\section{CONTENTS}

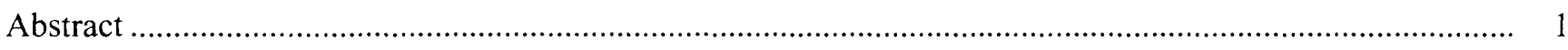

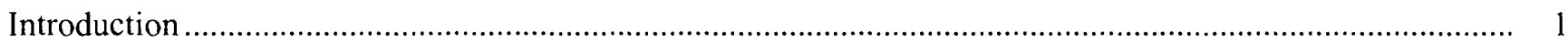

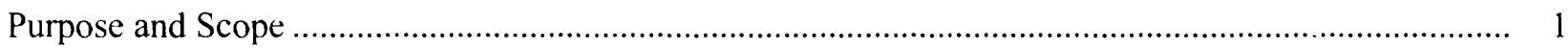

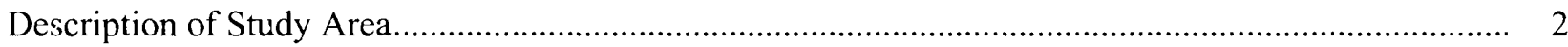

Acknowledgment .......................................................................................................... 2

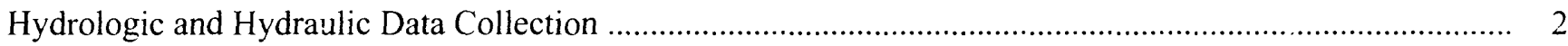

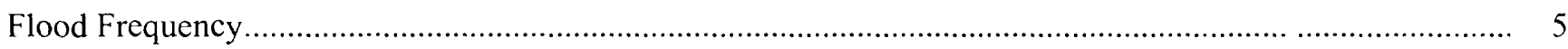

Model Selection and Development ......................................................................................................

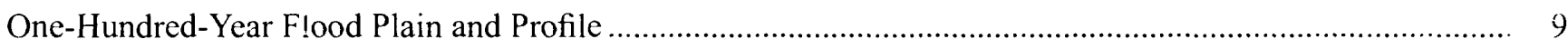

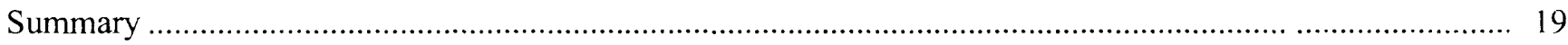

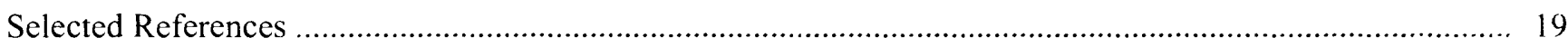

Appendix - List of Elevations Reference Marks...................................................................................... 21

\section{PLATE}

1. Map showing areal extent of the 100-year flood for Fourmile Branch at the Savannah Rive:- Site, near Aiken, South Carolina [in pocket]

\section{FIGURES}

1. Map showing Savannah River Site with site areas and streams in Aiken, Allendale, and Barriweli Counties. S.C.

2. Map showing boundaries, drainage basins, and stream locations at the Savannah River Site, S.C.....

3. Graph showing relation of percentage impervious area and 100-year recurrence interval flow for Fourmile Branch at Road A-7, Savannah River Site, S.C.

4-7. Graphs showing the flood profile of Fourmile Branch, Savannah River Site, S.C., from:

4. Station 16000 to Station 24000 and Station 24000 to Station 32000 10

5. Station 32000 to Station 40000 and Station 40000 to Station 48000 11

6. Station 48000 to Station 56000 and Station 56000 to Station 64000 12

7. Station 64000 to Station 72000 and Station 72000 to Station 78771

\section{TABLES}

1. Summary of 100-year recurrence-interval flows for Fourmile Branch, Aiken and Barnwell Counties, S.C.

2. Cross-section name, station, location, type, and 100-year flow, flood-plain width, and water-surface elevation for selected cross sections of Fourmile Branch, Aiken and Barnwell Counties, S.C. 


\begin{tabular}{rll}
\hline Multiply & By & To obtain \\
\hline foot $(\mathrm{ft})$ & 0.3048 & meter \\
foot per mile $(\mathrm{ft} / \mathrm{mi})$ & 0.1894 & meter per kilometer \\
cubic foot per second $\left(\mathrm{ft}^{3} / \mathrm{s}\right)$ & 0.02832 & cubic meter per second \\
square $\mathrm{mlle}^{2}\left(\mathrm{mi}^{2}\right)$ & 2.590 & square kilometer \\
\hline
\end{tabular}

Sea Level: In this report, "sea level" refers to the National Geodetic Vertical Datum of 1929--a geodetic datum derived from a general adjustment of the first-order level nets of the United States and Canada. formerly called Sea Level Datum of 1929.

Acronyms used in this report:

$\begin{array}{ll}\text { ERM } & \text { Elevation reference mark } \\ \text { NRCS } & \text { Natural Resources Conservation Service } \\ \text { SRS } & \text { Savannah River Site } \\ \text { USDOE } & \text { U.S. Department of Energy } \\ \text { USGS } & \text { U.S. Geological Survey } \\ \text { USC\&GS } & \text { U.S. Coastal and Geodetic Survey } \\ \text { WSPRO } & \text { Computer model for Water Surface Profile Computations }\end{array}$

In this report, the station number represents the distance in feet upstream from the mouth of the subject stream. For example, Station 37600 on Fourmile Branch is 37,600 feet upstream from the mouth of Fournile Branch.

In this report, the words "right" and "left" refer to the directions that would be reported by an observer facing downstream. 


\title{
Determination of the 100-Year Flood Plain on Fourmile Branch at the Savannah River Site, South Carolina, 1996
}

\author{
By Timothy $\mathrm{H}$. Lanier
}

\section{Abstract}

A hydrologic analysis was made to estimate the 100-year recurrence-interval flow for Fourmile Branch. The analysis showed the South Carolina upper Coastal Plain regional rural- and urban-regression equations were applicable for the Fourmile Branch drainage basin. This was verified by analysis of the flood-frequency data collected from U.S. Geological Survey gaging station 02197342 on Fourmile Branch.

Cross sections were surveyed throughout the reach, and other pertinent data such as flow resistance and land use were collected. The surveyed cross sections and computed 100-year recurrence-interval flows were used in a step-backwater model to compute the 100 -year flood profile for Fourmile Branch. The profile was used to delineate the 100-year flood plain on a topographic map. Results are also provided in tabular and graphical formats.

\section{INTRODUCTION}

In 1951, the U.S. Department of Energy (USDOE), formerly the Atomic Energy Commission, created the Savannah River Site (SRS) to produce nuclear materials for national defense. The SRS is located in parts of Aiken, Barnwell, and Allendale Counties, South Carolina. The operation of the first nuclear production reactor, in area R, began in 1953 (fig. 1). In addition, there are four other nuclear reactors at the SRS, located in areas $\mathrm{C}, \mathrm{K}, \mathrm{L}$, and $\mathrm{P}$. Reactors in areas $\mathrm{R}$ and $\mathrm{P}$ were permanently deactivated in 1964 and 1991, respectively, and except for the restart testing of $\mathrm{K}$ reactor in 1991, all of the remaining reactors have been placed on stand-by since the late 1980's. Other areas on the SRS include reactor materials (area $\mathrm{M}$ ), separation (areas $\mathrm{F}$ and $\mathrm{H}$ ), waste mar agement (areas E, F, H, S, Y, and Z), heavy-water processing (area D), administration (areas A, R, and CS), the Savannah River Ecology Laboratory. and the Savannah Technology Center (Arnett and others, 1992).

In 1992, the U.S. Geological Survey (USGS), in cooperation with the USDOE, initiated an investigation to determine the areal extent of the inundation caused by the 100-year recurrence-interval flow (100-year flow) for the Savarnah River along the SRS boundary and for the major streams and their tributaries on the SRE, with the exception of Lower Three Runs. This report describes the inundation caused by the $10 \mathrm{C}$ year flow on Fourmile Branch.

\section{Purpose and Scope}

This report documents the approximate boundaries of the 100-year flood plain on the SRS for Fourmile Branch (fig. 2). One-hundred-yecr flows at selected locations, graphical and tabulcr profiles of the 100-year flood are listed in tables. Descriptions and elevations of benchmarks for Fourmile Branch are listed in the appendix.

Less-than-detailed methods, which require less cross-sectional definition, were used to compute the 100-year flood-plain boundaries. In particular, cross sections were surveyed primarily at road crossings or other easily accessible locations. 
Intermediate cross sections were interpolated using these surveyed cross sections and 7.5-minute topographic maps (U.S. Geological Survey, 1963-65b). This method was requested by the USDOE, because greater accuracy was not warranted.

\section{Description of Study Area}

The SRS occupies more than $300 \mathrm{mi}^{2}$ along the Georgia-South Carolina border in parts of Aiken, Barnwell, and Allendale Counties, South Carolina. The southwestern boundary of the SRS is formed by the Savannah River. The five major streams that drain into the Savannah River from the SRS are Upper Three Runs, Fourmile Branch, Pen Branch, Steel Creek, and Lower Three Runs (fig. 2). The SRS is located in the upper Coastal Plain of South Carolina, which encompasses about 20 percent of the State (fig. 1). The general topography of the upper Coastal Plain consists of rounded hills with gradual slopes; however, some areas of highly irregular terrain exist in the province, and some elevations exceed $700 \mathrm{ft}$ above sea level. The highest elevation on the SRS is approximately $420 \mathrm{ft}$ above sea level, near Tims Branch and the northwest boundary of SRS (fig. 2). The land-surface elevation at the boundary of the upper and lower Coastal Plains, located southeast of the SRS, is usually less than $200 \mathrm{ft}$ above sea level. Upper Coastal Plain stream slopes range from 5 to $20 \mathrm{ft} / \mathrm{mi}$, and many of the streams are bordered by swamps with wide flood plains relative to the size of the stream (Zalants, 1990).

The study area is the Fourmile Branch Basin (pl. 1). Fourmile Branch begins just upstream from Road F (fig. 1; pl. 1), and flows into the Savannah River south of Augusta, Ga., at river mile 150.7 (pl. 1). Fourmile Branch enters the Savannah River Swamp approximately $11,400 \mathrm{ft}$ upstream from its confluence with the Savannah River; downstream from this point, Fourmile Branch becomes braided and mixes with flow from the Savannah River. The downstream study limit is the confluence of Fourmile
Branch and the Savannah River; however, 100year flood-plain and profile comfitations begin upstream from where Fourmile Branch enters the Savannah River Swamp because of the effect of backwater from the Savannah River (pl. 1). The drainage area of Fourmile Branch before it enters the Savannah River Swamp is $23.0 \mathrm{mi}^{2}$.

The upstream study limit is located at Road $\mathrm{F}$; this point was selected because the drainage area upstream of Road F is less then $1.0 \mathrm{mi}^{2}$, and there is no urbanization or road crossings upstream of this point. All of the Fcurmile Branch drainage basin lies within the SRS, and contains significant industrialization, which includes areas C, CS, E, F, and H (fig. 1).

\section{Acknowledgment}

The author is grateful to Lee Davis, USDOE, for his logistical and administrative support of this project.

\section{HYDROLOGIC AND HYDRAULIC DATA COLLECTION}

Hydrologic data, which includes drainage area, soil type, impervious area, and peak-flow records at USGS gaging stations, were used to estimate the 100-year flow for Fourmile Branch. The drainage area for the basin was delineated using 7.5-minute series topographic maps (U.S. Geological Survey, 1963-65b) at selected locations along the reach. These locations were selected based on major tributary confluences, changes in drainage-area shape, and changes of imperviousness within the drainage basin. Soil types were determined from the Natural Resources Conservation Service (NRCS) [formerly the Soil Conservation Service] soil reports of Aiken and Barnwell Counties and the Savannah River Plant Area (Rogers, 1977; 1985; 1990). Urbanized areas in the drainage basin were determined from aerial photographs, 7.5-minute series 


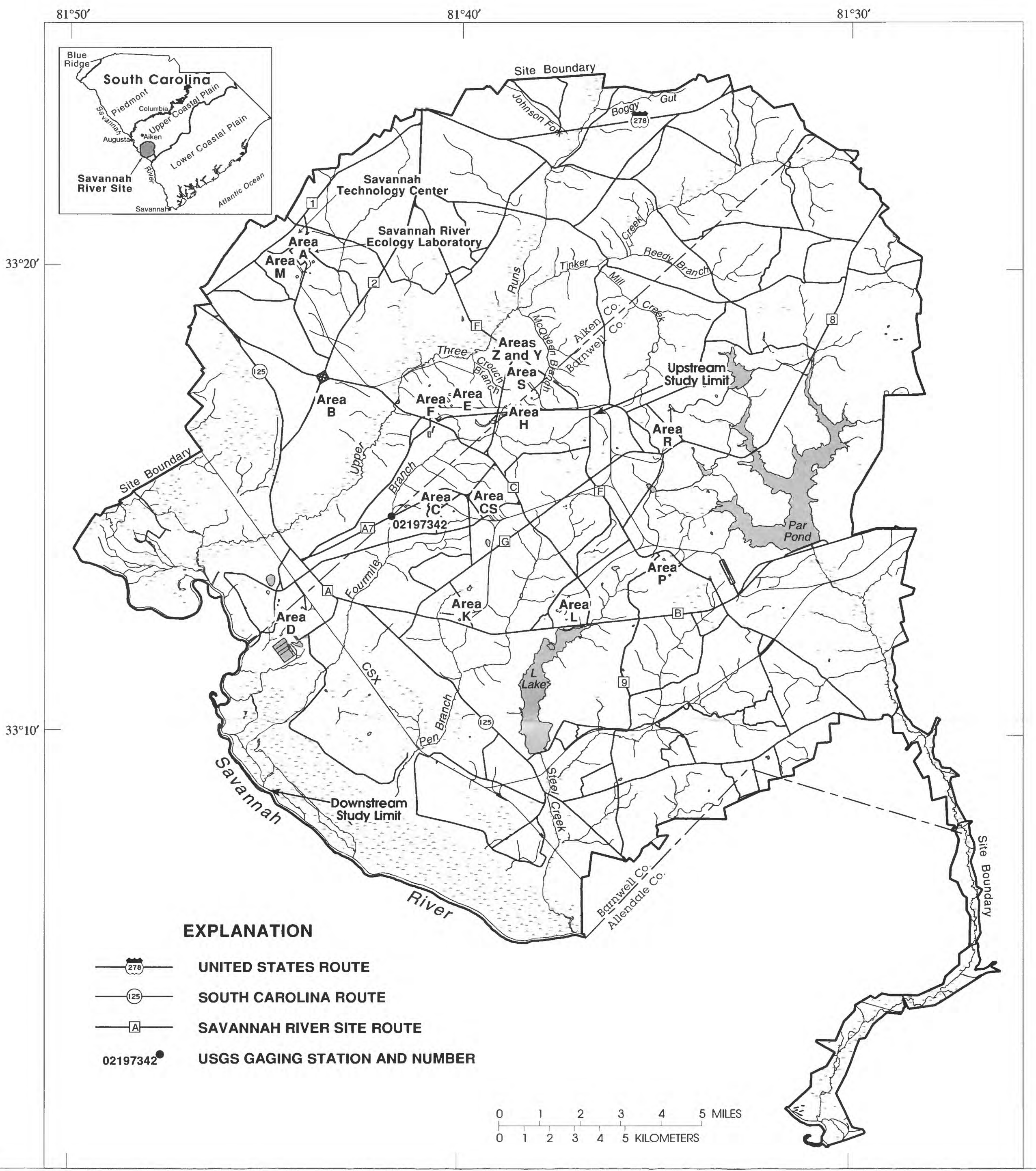

Figure 1. Savannah River Site with site areas and streams in Aiken, Allendale, and Barnwell Counties, S.C. 
topographic maps (U.S. Geological Survey, 1963-65b), the SRS Atlas (Savannah River Site, 1994), and field inspections. Only urbanization in and around the industrial areas of the basin, which include areas C, CS, E, F, and H, were considered. Paved roads outside of these areas were not included. Percent-imperviousness data associated with urbanized areas were obtained from Cronshey and others (1986). Peak-flow data were obtained from USGS gaging station 02197342, Fourmile Branch at Road A-7 (fig. 1). These peak-flow data were used to verify the methods of regionalization of selected recurrence-interval flows described by Guimaraes and Bohman (1992) and Bohman (1992).

Cross sections for the step-backwater analysis of Fourmile Branch were taken upstream and (or) downstream from bridge and culvert crossings, along road grades at these crossings, and at selected locations along the streams, such as natural or man-made expansions or contractions and powerline right-of-ways. In addition, elevation data and structural geometry for all bridges and culverts were determined. Synthesized cross sections were developed using surveyed cross-sectional data and 7.5-ninute series topographic maps (U.S. Geological Survey, 1963-65b).

Cross-section elevations were referenced to sea level. In areas where no elevation reference marks (ERM) were located, a global positioning system was used to establish temporary ERM's. Standard surveying levels were used to reference the temporary ERM's to more permanent structures.

Manning's roughness coefficients used in the hydraulic computations were estimated for the channels and flood plains using engineering judgement. Coefficient estimates were based on field notes, photographs, and methods documented by Arcement and Schneider (1984) and Barnes (1967).

\section{FLOOD FREQUENCY}

The regionalized rural- and urban-regression equations developed by Guimaraes and Bohman (1992) and Bohman (1992) were used to compute the 100-year flow for Fourmile Branch. The use of these equations was verified by a hydrologic analysis of peak-flow data from gaging station 02197342, Fourmile Branch at Road A-7 (fig. 1). In the hydrologic analysis, the 100year flow was computed using the log-Pearson method and 23 years of peak-flow data; this 100 year flow was compared to the 100-year flow computed using the regional rural- and urbanregression equations. This comparison showed that the regional rural- and urban-regression equations reasonably describe the 100-year flows of Fourmile Branch.

By using the peak-flow data of gaging station 02197342 , a 100 -year flow of $1,080 \mathrm{ft}^{3} / \mathrm{s}$ was computed using the log-Pearson method. However, the 100-year flow computed with the regional rural-regression equation was $661 \mathrm{ft}^{3} / \mathrm{s}$. This large difference in computed flows is probably the result of the 5.0-percent imperviousness of the basin. However, the lower limit of imperviousness used to develop the regional urbanregression equations presented by Bohman (1992) is 10 percent. Therefore, a relation of impervious area to flow was established for the drainage area of station 02197342, using the rural flows which assume no significant imperviousness and the urban-regional flows using 10- to 50-percent imperviousness (fig. 3). The relation and an impervious area of 5.0 percent were used to obtain a 100 -year flow of $1,170 \mathrm{ft}^{3} / \mathrm{s}$. This flow was adjusted using methods described in Guimaraes and Bohman (1992) for determining flood frequency at or near a gaged site on the same stream. A 100-year flow of $1,110 \mathrm{ft}^{3} / \mathrm{s}$ was obtained, compared to $1,080 \mathrm{ft}^{3} / \mathrm{s}$ computed by log-Pearson methods. The flows are well within the 95-percent confidence limits of both methods. Therefore, the regionalized rural and urbanregression equations were used to compute the 100-year flows on Fourmile Branch. 


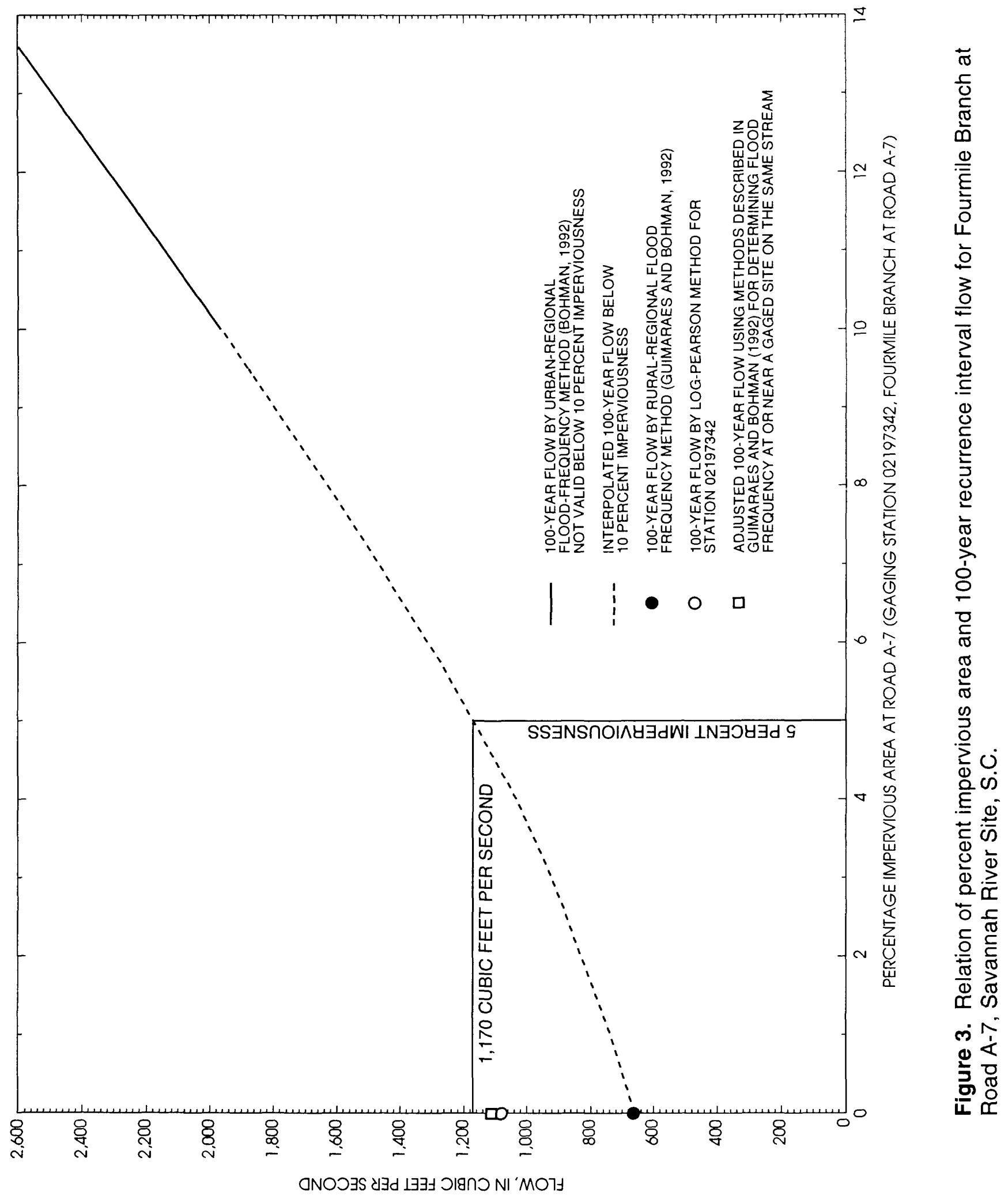


The equations are:

for rural Upper Coastal Plain watersheds (Guimaraes and Bohman, 1992),

$$
\mathrm{RQ}_{100}=116(\mathrm{~A})^{0.69},
$$

and for urban watersheds (Bohman, 1992),

$$
\mathrm{UQ}_{100}=10.4(\mathrm{~A})^{0.506}(\mathrm{TIA})^{0.932}\left(\mathrm{RQ}_{100}\right)^{0.280} \text {, }
$$

where

$\mathrm{RQ}_{100}$ is the 100-year recurrence-interval flow for rural drainage basins, In cubic feet per second;

A is the drainage area, in square miles;

$\mathrm{UQ}_{100}$ is the 100 -year recurrence-interval flow for urban drainage basins, in cubic feet per second; and

TIA is the total impervious area, in percent of total drainage area.

Equation 1 requires that the drainage areas be greater than $4.4 \mathrm{mi}^{2}$ and less than $1,720 \mathrm{mi}^{2}$. However, the relation was extended downward to $1.04 \mathrm{mi}^{2}$, because no other regional-regression equations specific to South Carolina were available. This extrapolation seems to be viable, because the logarithmic regional relation is linear. In addition, the relations for other physiographic provinces are generally linear throughout the range of data, and therefore, it is expected that the relation for the upper Coastal Plain could be extrapolated below a drainage area of $4.4 \mathrm{mi}^{2}$.

Equation 2 requires that the impervious area be greater than 10 percent, and the drainage area be greater than $0.18 \mathrm{mi}^{2}$ and less than $41.0 \mathrm{mi}^{2}$. The subbasins of Fourmile Branch meet the drainage area requirement for urbanized basins; however, the impervious area of the subbasins is typically less than 10 percent. Therefore, the previously described method to adjust flows for urbanization at Station 02197342 was used to compute flows for the subbasins which had an imperviousness of less than 10 percent.

The 100-year flow was computed at 15 locations on Fourmile Branch. The drainage area of nine of these sites was within 50 percent of the drainage area of the Station 02197342, therefore the flows were adjusted using the methods described in Guimaraes and Bohman (1992). The results of the hydrologic analysis on Fourmile Branch are presented in table 1.

\section{MODEL SELECTION AND DEVELOPMENT}

Water-surface elevations for the 100-year flows were computed for Fourmile Branch by using either the USGS/Federal Highways Administration step-backwater water-surface profile computer model (WSPRO) (Shearman and others, 1986; Shearman, 1990), or where flow is affected by backwater from the Savannah River, data from Lanier (1996) were used. The WSPRO model can compute backwater caused by bridges without subdividing the reach; however, the reach must be subdivided at culverts and a separate culvert-flow computation must be made to determine the backwater caused by the culvert. The culvert backwater was calculated using the USGS A-526 culvertflow model (Bodhaine, 1968). The computed water-surface elevation at the approach to the culvert was used as the initial water-surface elevation for the WSPRO analysis of the next upstream reach.

The downstream limit of the Fourmile Branch study area was located at the confluence of the Savannah River. Because the drainage area of the Savannah River is much larger than the drainage area of Fourmile Branch, it is assumed that at the time of the 100-year flood, the flow in Fourmile Branch would have peaked and receded before peak flow occurred on the Savannah River. 
Table 1.--Summary of 100-year recurrence-interval flows for Fourmile Branch, Aiken and Barnwell Counties, S.C.

$\left[\mathrm{mi}^{2}\right.$, square miles; $\mathrm{ft}^{3} / \mathrm{s}$, cubic feet per second; $\mathrm{ft}$, feet; --, cross section not surveyed; *, impervious area less than 1 percent.]

\begin{tabular}{|c|c|c|c|c|}
\hline $\begin{array}{l}\text { Location } \\
\text { (plate 1) }\end{array}$ & $\begin{array}{c}\text { Drainage } \\
\text { area } \\
\left(\mathrm{mi}^{2}\right)\end{array}$ & $\begin{array}{c}\text { Percentage } \\
\text { of } \\
\text { impervious } \\
\text { area }\end{array}$ & $\begin{array}{c}\text { One- } \\
\text { hundred- } \\
\text { year flow } \\
\left(\mathrm{ft}^{3} / \mathrm{s}\right)\end{array}$ & $\begin{array}{l}\text { Cross- } \\
\text { saction } \\
\text { name }\end{array}$ \\
\hline Station 21707; Road A-12.2 & 21.9 & 3 & ${ }^{1} 1,380$ & BR30 \\
\hline Station 32057; at Road A & 18.7 & 4 & ${ }^{\prime} 1,400$ & BR70 \\
\hline $\begin{array}{l}\text { Station } 38000 ; 5,943 \mathrm{ft} \text { upstream from Road } \mathrm{A} \text { and } \\
3,650 \mathrm{ft} \text { downstream from Road } 3\end{array}$ & 17.1 & 4 & ${ }^{1} 1,320$ & - \\
\hline $\begin{array}{l}\text { Station } 39950 \text {; upstream from the confluence with } \\
\text { an unnamed tributary; } 1,700 \mathrm{ft} \text { below Road } 3\end{array}$ & 13.3 & 5 & ${ }^{1} 1,170$ & S97.5 \\
\hline Station 44888; Road A-7 & 12.5 & 5 & 11,110 & EMB \\
\hline $\begin{array}{l}\text { Station } 49750 ; 4,862 \mathrm{ft} \text { upstream from Road A-7 } \\
\text { and 5,372 ft downstream from Road C-4 }\end{array}$ & 11.4 & 5.5 & ${ }^{1} 1,060$ & -- \\
\hline $\begin{array}{l}\text { Station 52500: } 2.622 \mathrm{ft} \text { downstream from } \\
\text { Road C-4 }\end{array}$ & 10.7 & 5.5 & ${ }^{1} 1,030$ & $-\cdot$ \\
\hline Station 55350: $228 \mathrm{ft}$ upstream from Road C-4 & 8.15 & 5 & 1823 & - \\
\hline Station $59623 ; 315 \mathrm{ft}$ upstream from Road C & 6.96 & 2 & 1590 & - \\
\hline Station 63813: $340 \mathrm{ft}$ downstream from Road 4 & 6.08 & 3 & 570 & $-\cdot$ \\
\hline Station $65238 ; 1,085 \mathrm{ft}$ upstream from Road 4 & 4.50 & * & 327 & -- \\
\hline Station $71750 ; 3,918 \mathrm{ft}$ upstream from Road E-1 & 3.66 & * & 284 & -- \\
\hline $\begin{array}{l}\text { Station } 73400 ; 5,568 \mathrm{ft} \text { upstream from Road E- } 1 \\
\text { and } 5,320 \mathrm{ft} \text { downstream from Road F }\end{array}$ & 1.91 & * & 181 & -- \\
\hline Station $76750 ; 1,970 \mathrm{ft}$ downstream from Road $F$ & 1.29 & * & 138 & -- \\
\hline Station 78720; at Road F & 1.04 & * & 119 & SE240 \\
\hline
\end{tabular}

'Flow adjusted using data from gaging station 02197342. 
The elevation of the 100-year flood on the Savannah River at the mouth of Fourmile Branch is $106.0 \mathrm{ft}$, which intersects Fourmile Branch at Station 22625. Therefore, due to the backwater of the Savannah River, the initial Fourmile Branch water-surface elevation was computed by slope conveyance at cross section SEC10, which is located 18,287 ft upstieam of the confluence of Fourmile Branch and the Savannah River (pl. 1). The 100-year flood elevation on the Savannah River of $106.0 \mathrm{ft}$ intersects the 100-year flood elevation on Fourmile Branch at Station 19846.

\section{ONE-HUNDRED-YEAR FLOOD PLAIN AND PROFILE}

Fourmile Branch was analyzed from its confluence with the Savannah River to Road F (pl. 1). Station 0 is located at the confluence of Fourmile Branch and Savannah River. The 78,800-ft long study segment consists of 49-surveyed and 132 -synthetic cross sections. Within the study area, there are 4 highway bridges, 1 railway bridge, 5 culvert crossings, and 10 breached dams or old road beds that cross Fourmile Branch. The highway bridges are located on Roads A-12.2, A, C, and 4 at Stations 21707, 32057, 59308, and 64153, respectively (pl. 1). The CSX railway bridge crosses Fourmile Branch at Station 25806 (pl. 1). The culverts are located at Roads 3, A-7, C-4, E-1, and F at Stations 41650, 44888, 55122, 67832 , and 78720 , respectively (pl. 1). The breached dams/road beds are located at Stations 18457, 21885, 24807, 27132, 35870, 36307, 39930, 49654, 59391, and 64218 (pl.1). Roads 6-1, 6-2, 6-3, and A-6 are located at Stations $32650,33250,34020$, and 46475 , respectively, but do not cross Fourmile Branch. In the area of Fourmile Branch affected by backwater from the Savannah River, the 100-year flood-plain widths range from $1.150 \mathrm{ft}$ at Station 15850 to $350 \mathrm{ft}$ at Station 20500 (pl. 1). Outside of this area, the 100-year flood-plain widths range from $900 \mathrm{ft}$ at Station 58025 to $120 \mathrm{ft}$ at Station 68250 (pl. 1). Backwater caused by the road and railway bridges ranges from less than $0.1 \mathrm{ft}$ at $\operatorname{Road~C}$ to $2.0 \mathrm{ft}$ at the CSX Railway Bridge. The old roaci embankment just upstream of Road 4 causes $1.9 \mathrm{ft}$ of backwater. In addition, Roads A-7, C-4, and E-1 are overtopped by a depth of $2.7 \mathrm{ft}, 1.2 \mathrm{ft}$, and $1.0 \mathrm{ft}$, respectively. Graphical and tabular profiles of Fourmile Branch are shown in figures 4 through 7 and listed in table 2 , respectively. The areal extent of the inundation caused by the 100year flood on Fourmile Branch is shown in plate 1 . 


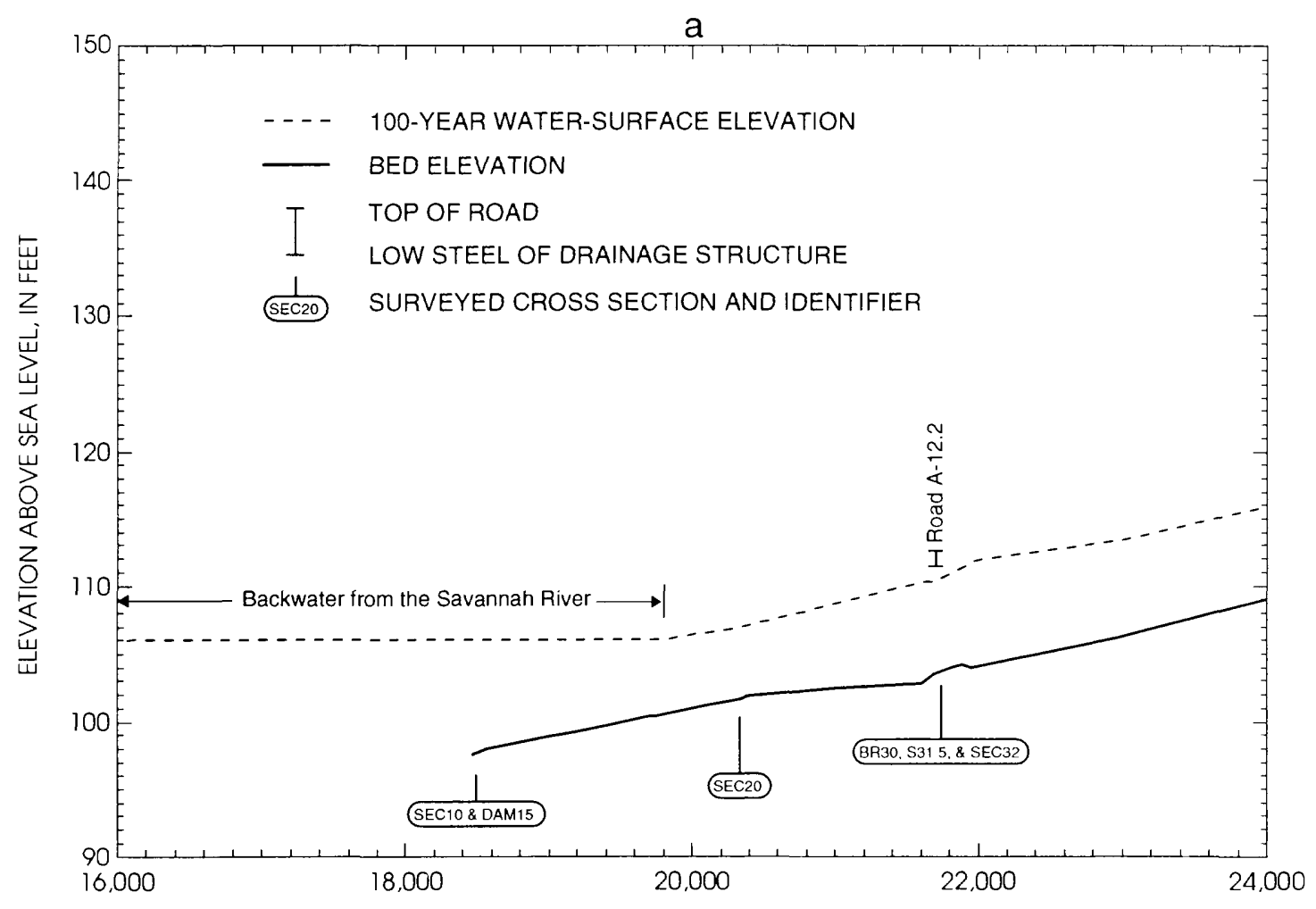

DISTANCE UPSTREAM FROM THE CONFLUENCE WITH SAVANNAH RIVER, IN FEET

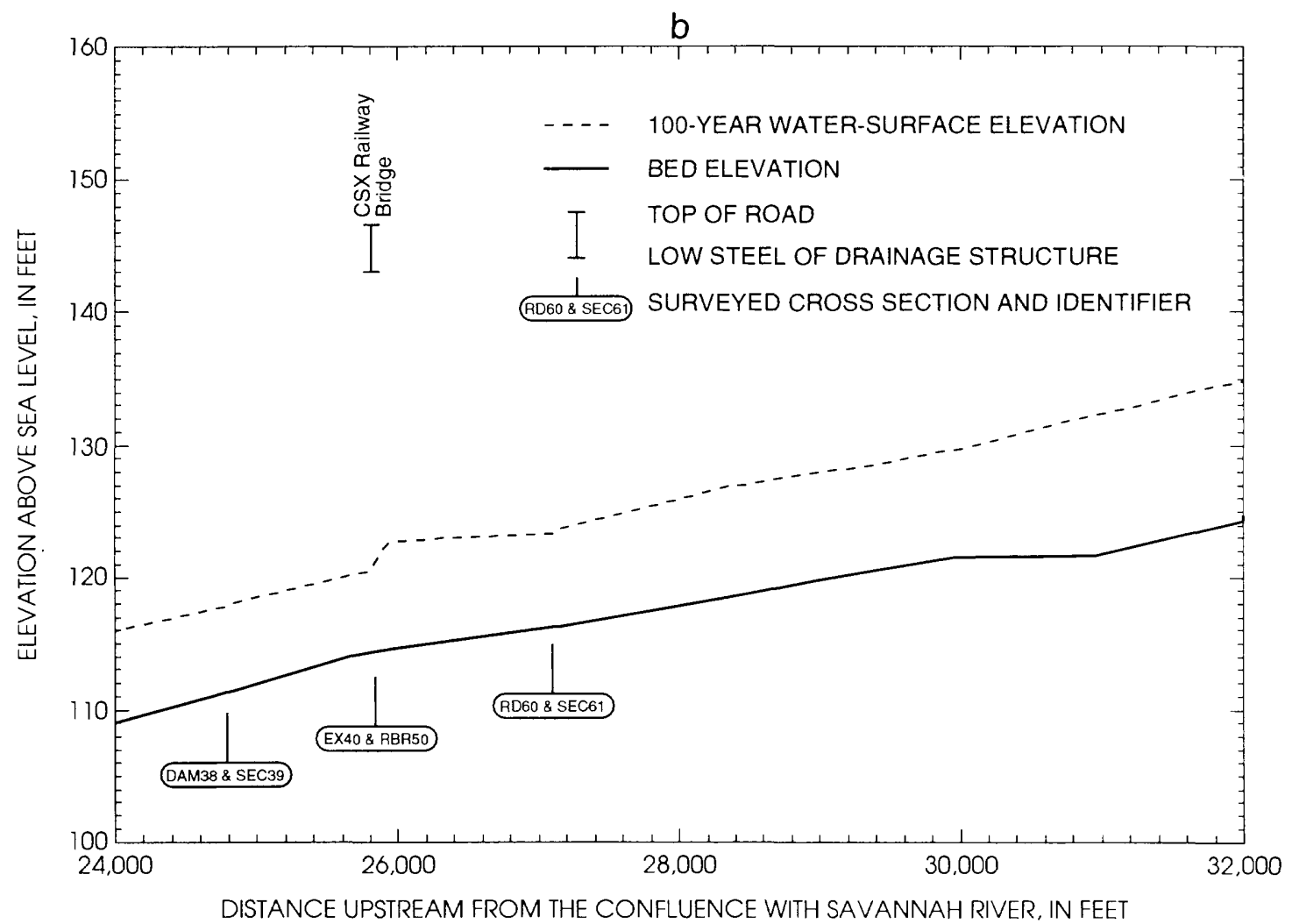

Figure 4. Flood profile of Fourmile Branch, Savannah River Site, S.C., from (a) Station 16000 to Station 24000 and (b) Station 24000 to Station 32000. 

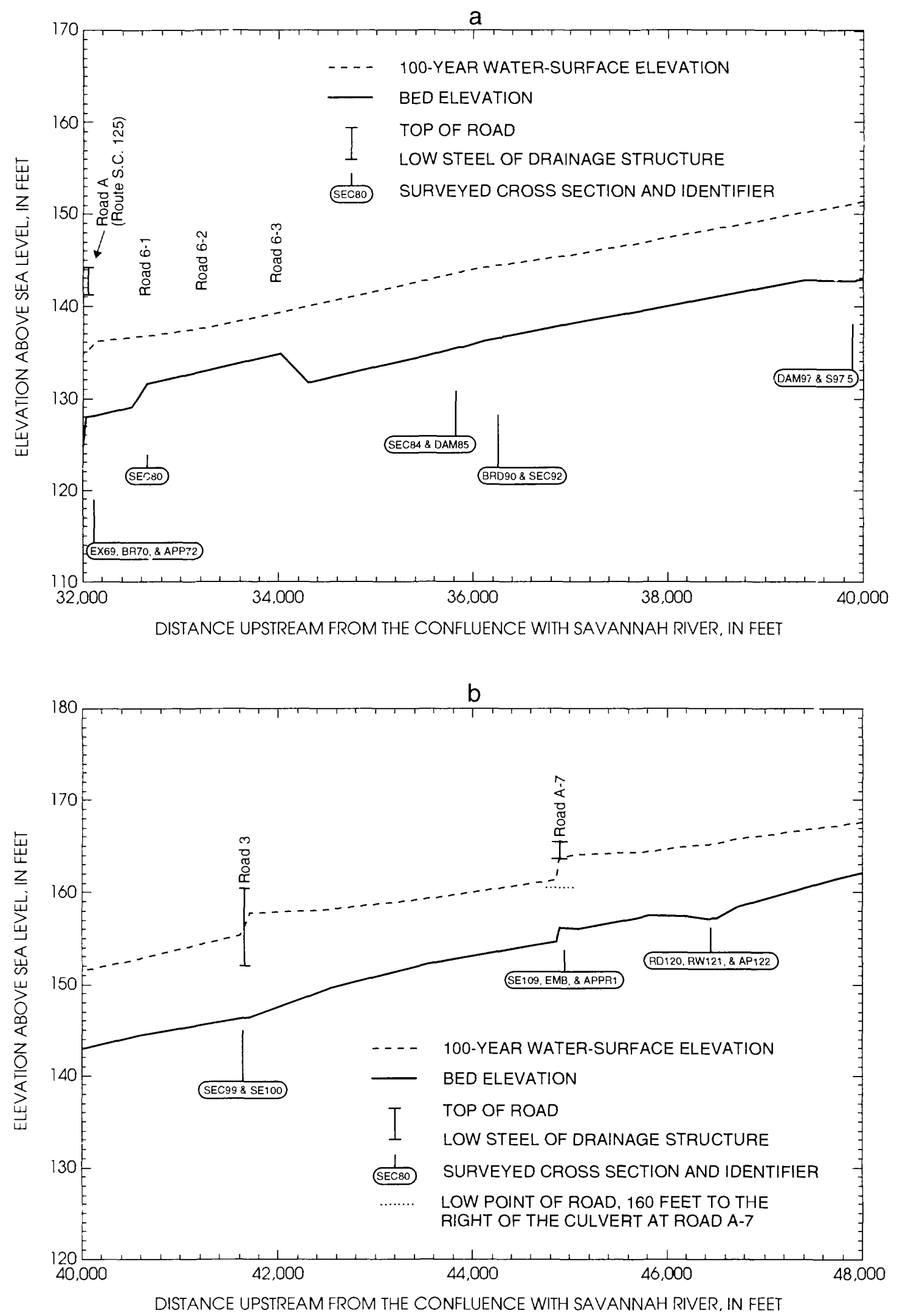

Figure 5. Flood profile of Fourmile Branch, Savannah River Site, S.C., from (a) Station 32000 to Station 40000 and (b) Station 40000 to Station 48000. 

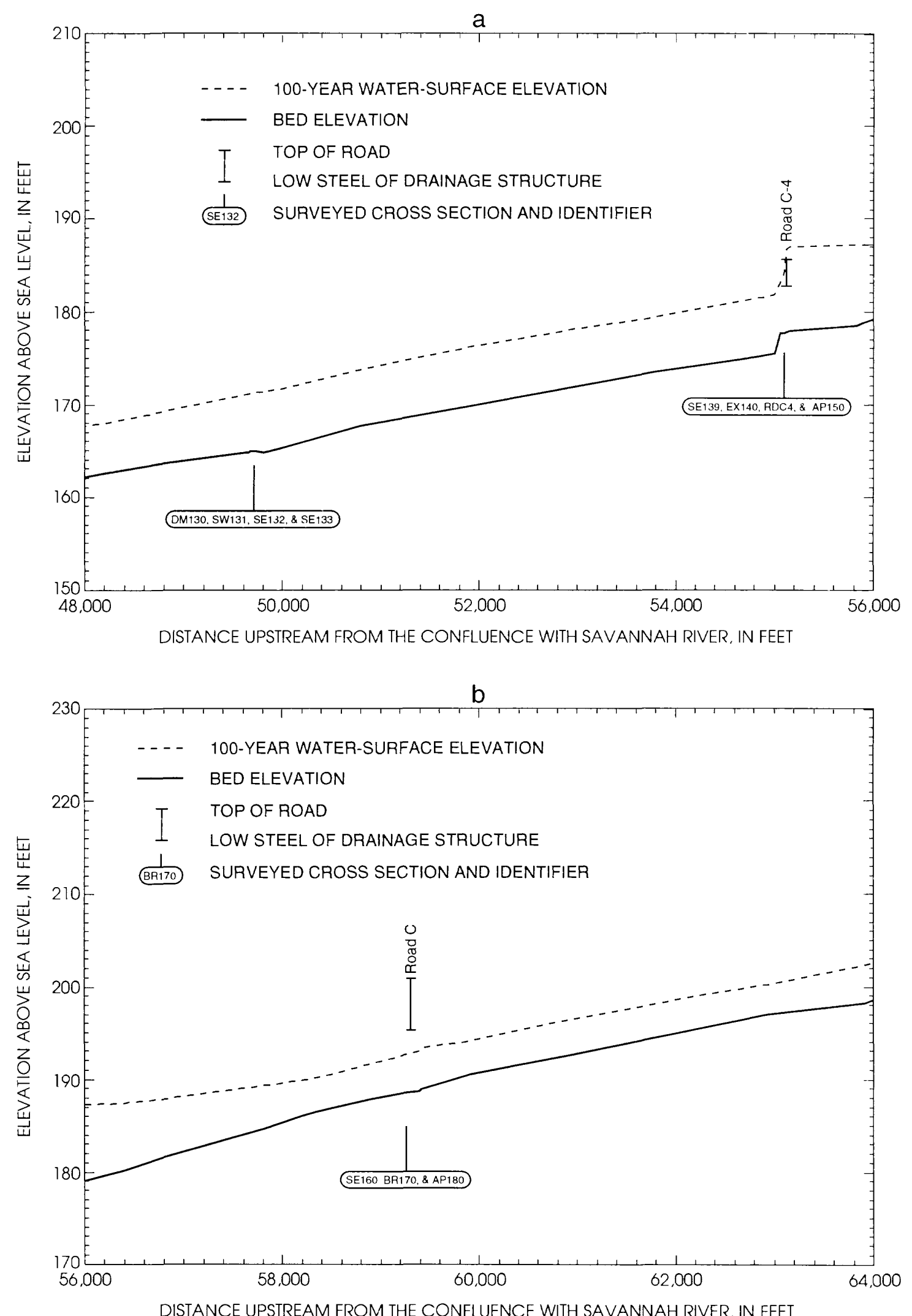

Figure 6. Flood profile of Fourmile Branch, Savannah River Site, S.C., from (a) Station 48000 to Station 56000 and (b) Station 56000 to Station 64000 . 

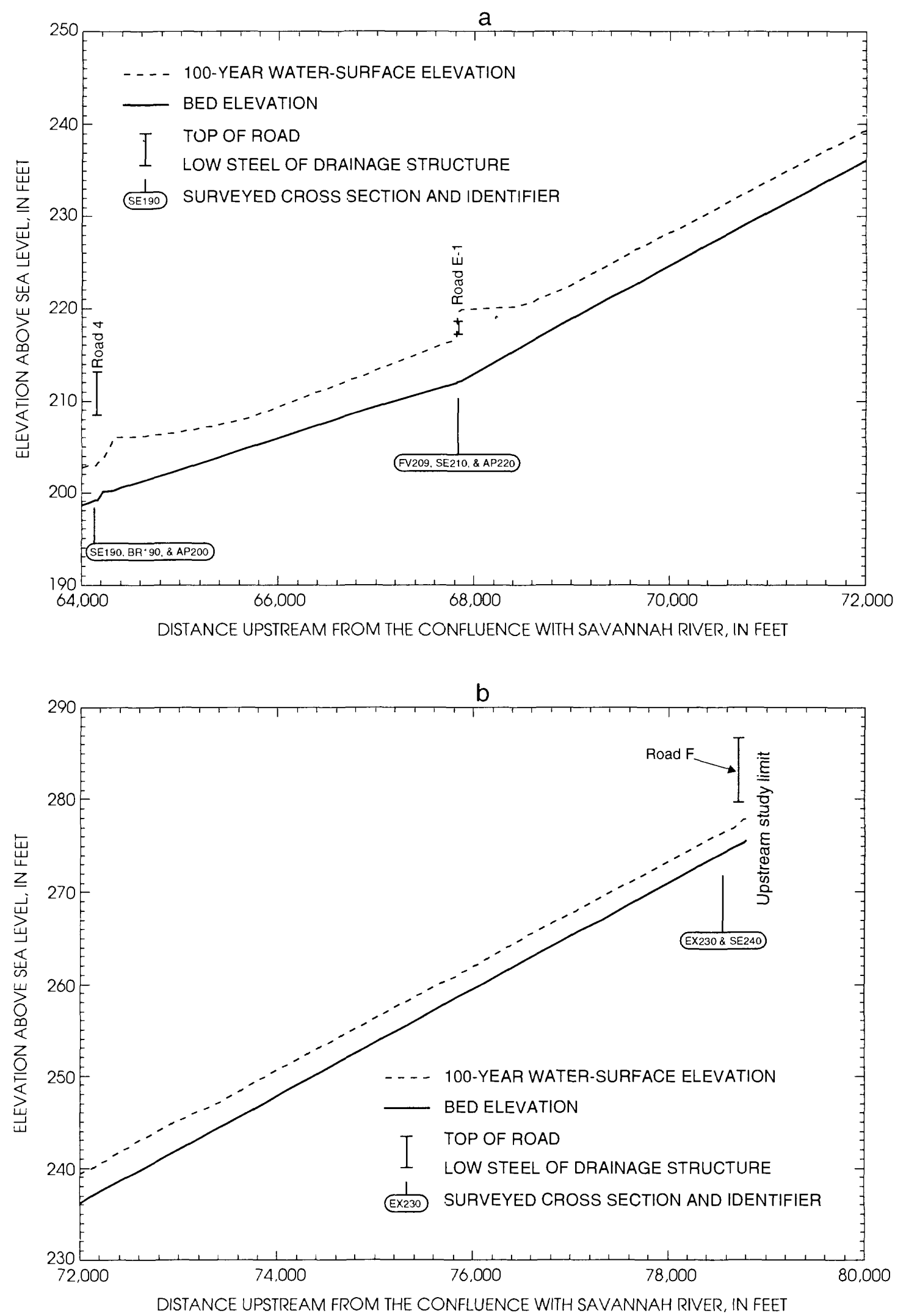

Figure 7. Flood profile of Fourmile Branch, Savannah River Site, S.C., from (a) Station 64000 to Station 72000 and (b) Station 72000 to Station 78771 . 


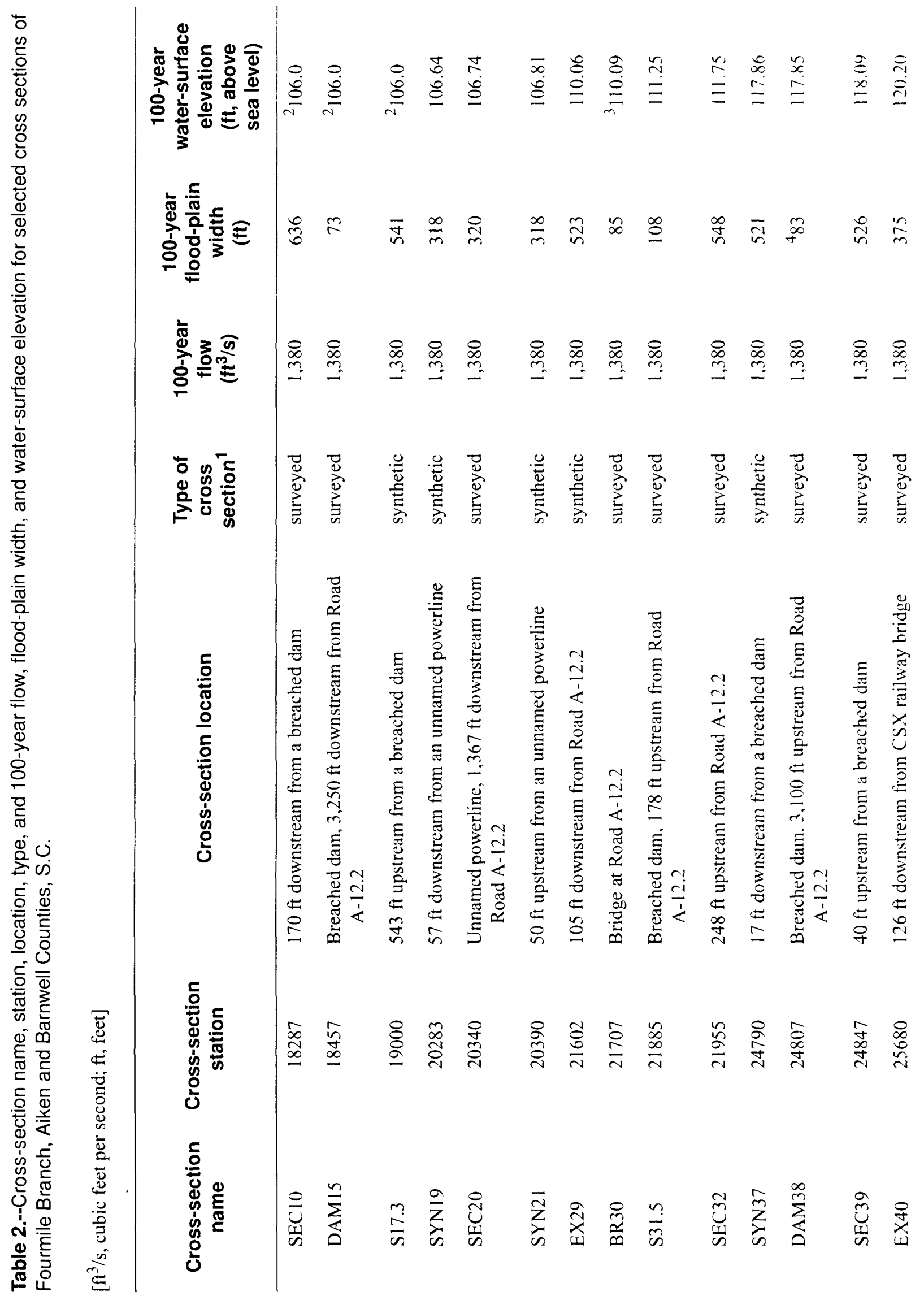




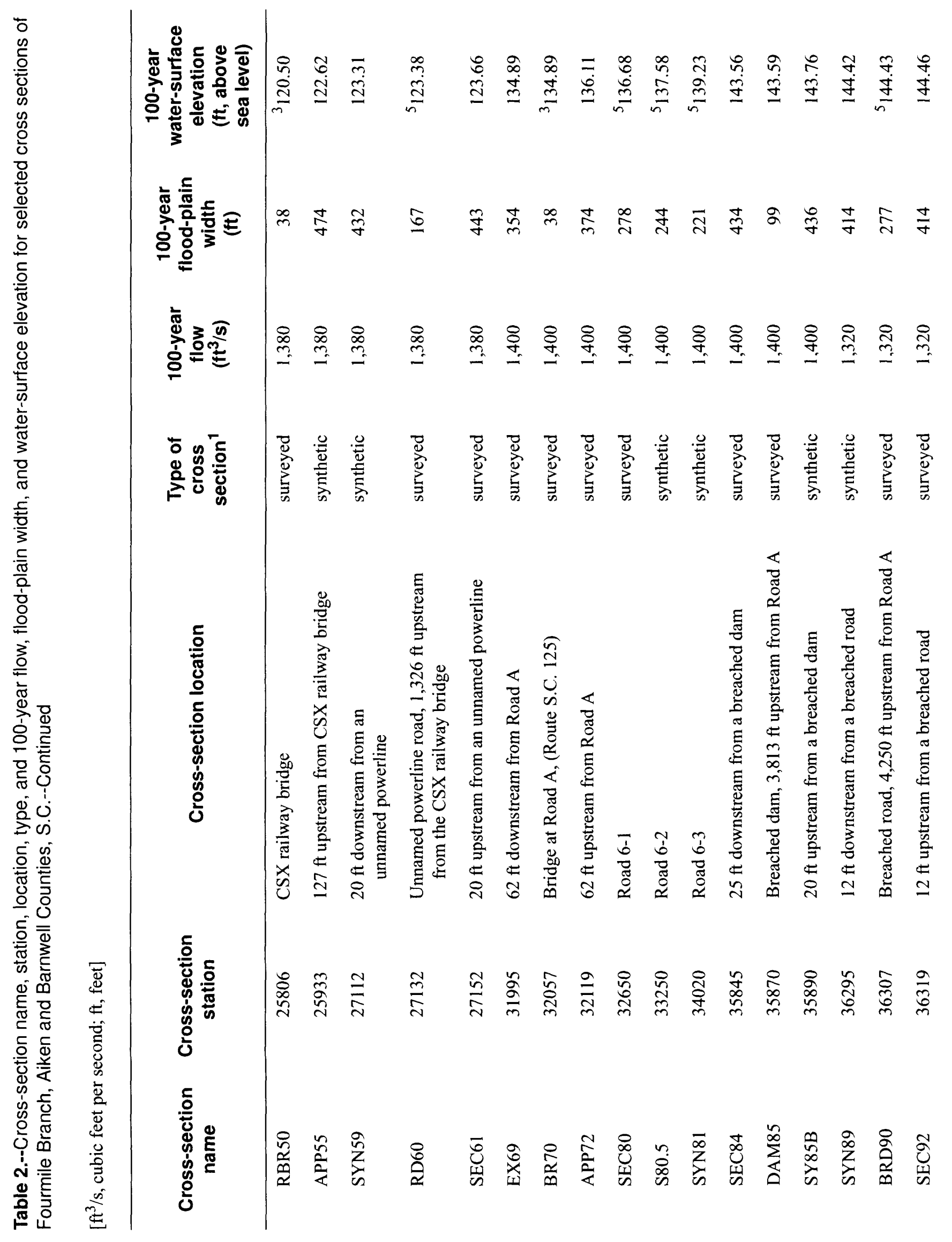




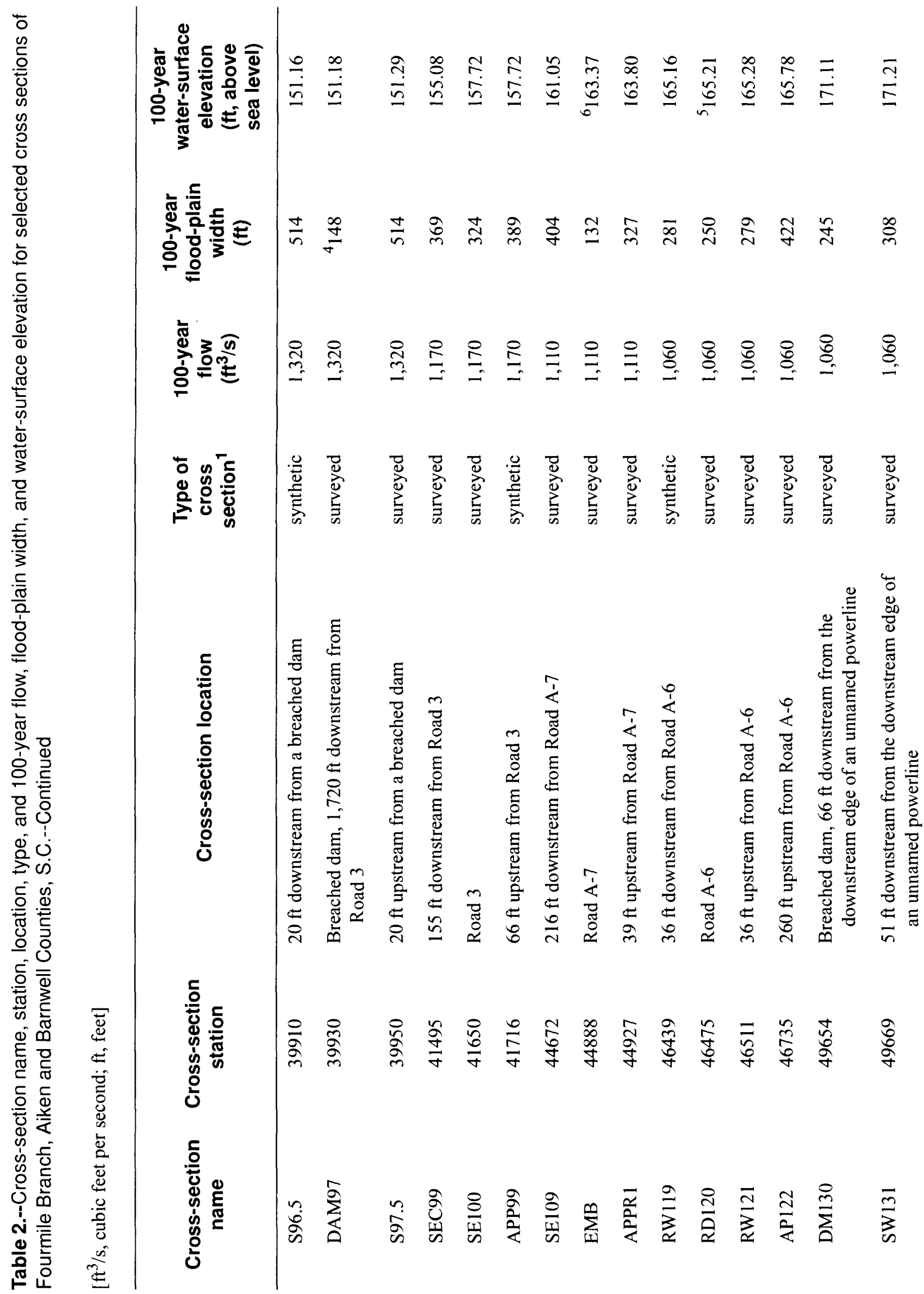




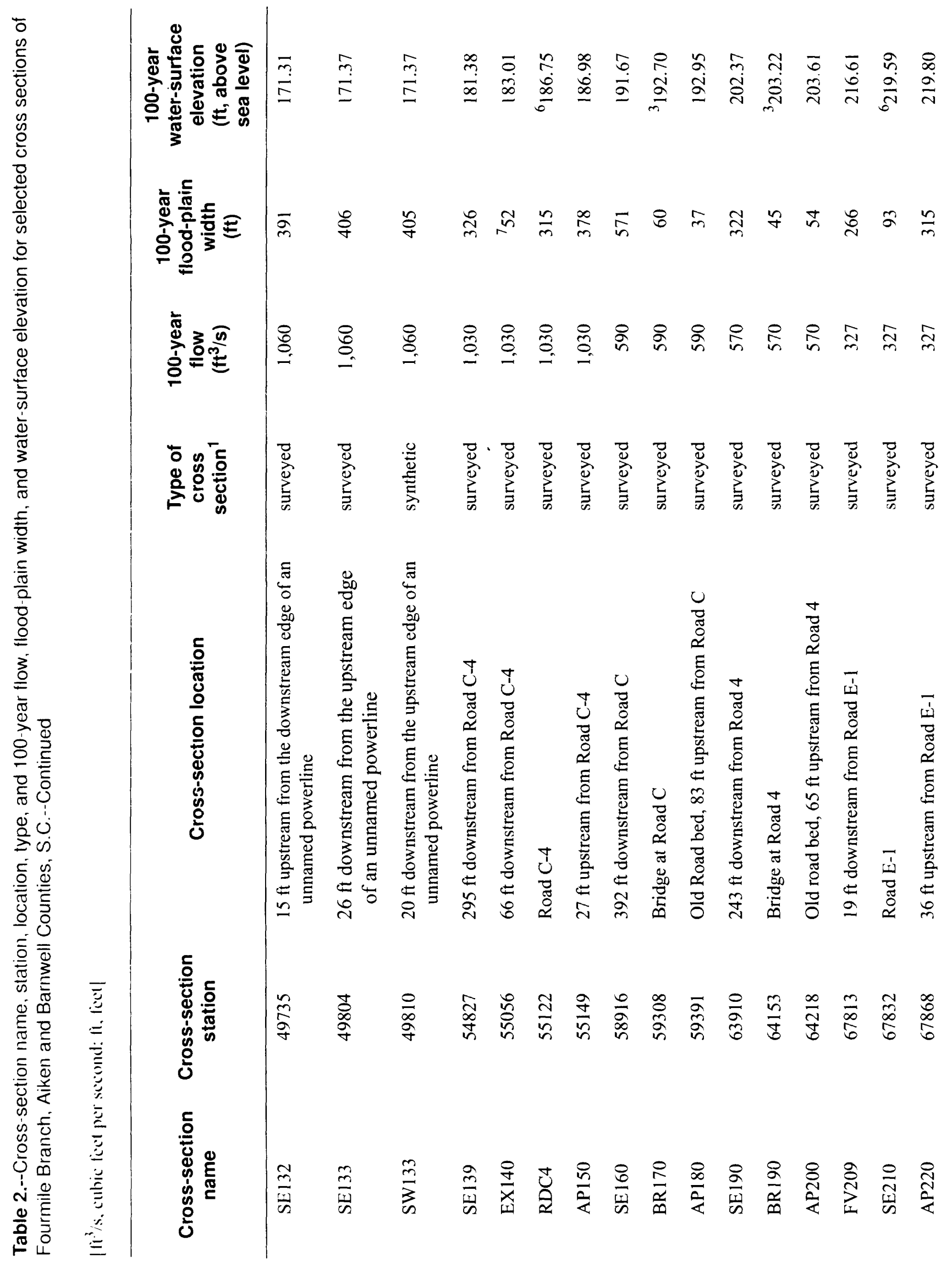




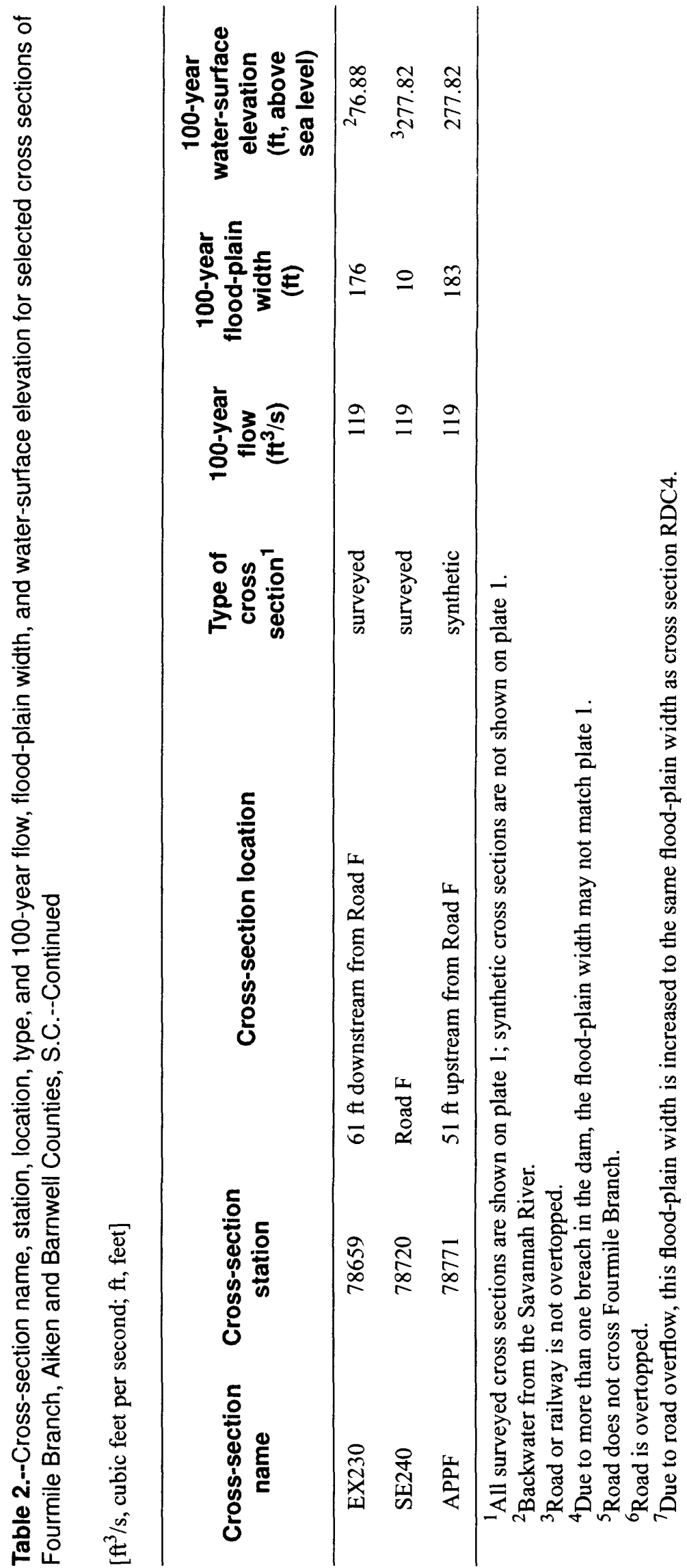




\section{SUMMARY}

In 1951, the U.S. Department of Energy, formerly the Atomic Energy Commission, created the Savannah River Site to produce nuclear materials for national deferse. The Savannah River Site occupies approximately 300 square miles along the Georgia-South Carolina border in parts of Aiken, Barnwell, and Allendale Counties, South Carolina. In 1992, the U.S. Geological Survey, U.S. Department of the Interior, in cooperation with the U.S. Department of Energy, initiated an investigation to determine the areal and vertical extent of inundation caused by the 100 -year recurrence-interval flood for the Savannah River along the Savannah River Site southwestern boundary, and for the major streams and their tributaries on the Savannah River Site, with the exception of Lower Three Runs.

This report includes a map of the 100-year flood plain and flood profile on Fourmile Branch. The results also are provided in tabular format. The 100-year flood-plain map and flood profile provide water-resource managers with a technical basis for making flood-plain management decisions that could minimize future flood problems and provide a basis for designing and constructing drainage structures along roadways.

A hydrologic analysis was made to estimate the 100-year recurrence-interval flow for Fourmile Branch and its trihutaries. This analysis showed the U.S. Geological Survey regional rural- and urban-regressior equations for South Carolina reasonably describe the 100 -year flows of Fourmile Branch.

Throughout the reach, sross sections were surveyed and other pertinent data such as flow resistance and land-use data were collected. The computed 100-year flows and surveyed cross sections were used in a step-backwater model to compute the 100-year flood plain for Fourmile Branch. The profiles computed by the step-backwater model were used to delineate the 100-year flood plain on topographic maps.

\section{SELECTED REFERENCES}

Arcement, G.J., Jr., and Schneider, V.R.. 1984, Guide for selecting Manning's roughness coefficients for natural channe's and flood plains: Federal Highway Administration Publication FHWA-TS-84-204, 62 n.

1989, Guide for selecting Manning's roughness coefficients for natural channels and flood plains: U.S. Geological Survey Water-Supply Paper 2339, 38 p.

Arnett, M.W., Karapatakis, L.K., Mamatey, A.R., and Todd, J.L., 1992, Savannah River Site environmental report for 1991: Westinghouse Savannah River Company Publication WSRC-TR-92-186, $562 \mathrm{p}$.

Barnes, H.H., Jr., 1967, Roughness characteristics of natural channels: U.S Geological Survey Water-Supply Paper 1849, $213 \mathrm{p}$.

Bodhaine, G.L., 1968, Measurenent of peak discharge at culverts by indirect methods: U.S. Geological Survey Techniques of WaterResources Investigations, book 3, chap. A3, $60 \mathrm{p}$.

Bohman, L.R., 1992, Determination of flood hydrographs for streams in South Carolina: Volume 2. Estimation of peak-discharge frequency, runoff volumes, and flood hydrographs for urban watersheds: U.S Geological Survey Water-Resources Investigations Report 92-4040, $79 \mathrm{p}$.

Chow, V.T., 1959, Open-Channel Hydraulics: New York, MacMillan Publishing Co., Inc., $522 \mathrm{p}$.

Cronshey, Roger; McCuen, R.H.; Miller, Norman; Rawls, Walter; Robbins, Sam; and Woodward, Don, 1986, Urban hydrology for small watersheds: Soil Conservation Service, Technical Release 55, Washington D.C., 94 p.

Guimaraes, W.B., and Bohman, L.R., 1992, Techniques for estimating magnitude and frequency of floods in South Carolina, 1988: U.S. Geological Survey Water-Resources Investigations Report 91-4157, $174 \mathrm{p}$.

Hulsing, Harry, 1967, Measurement of peak discharge at dams by indirect methods: U.S. 
Geological Survey Techniques of WaterResources Investigations, book 3, chap. A5, $29 \mathrm{p}$.

Lanier, T.H., 1996, Determination of the 100-year flood plain on Upper Three Runs and selected tributaries, and the Savannah River at the Savannah River Site, South Carolina,1995: U.S. Geological Survey Water-Resources Investigations Report 96-4014.

Matthai, H.F., 1967, Measurement of peak discharge at width contractions by indirect methods: U.S. Geological Survey Techniques of Water-Resources Investigations, book 3, chap. A4, 44 p.

Rogers, V.A., 1977, Soil Survey of Barnwell County, South Carolina, Eastern Part: U.S. Department of Agriculture, $52 \mathrm{p}$.

1985, Soil Survey of Aiken County Area, South Carolina: U.S. Department of Agriculture, $134 \mathrm{p}$.

-1990, Soil Survey of Savannah River Plant Area, Parts of Aiken, Barnwell, and Allendale Counties, South Carolina: U.S. Department of Agriculture, $127 \mathrm{p}$.

Savannah River Site, 1994, Savannah River Site atlas including off-site locations and index, OSR3-158, $40 \mathrm{p}$.

Shearman, J.O., 1990, User's manual for WSPRO--a computer model for water surface profile computations: Federal Highway Administration Publication FHWA-IP-89$027,187 \mathrm{p}$.

Shearman, J.O., Kirby, W.H., Schneider, V. R., and Flippo, H.N., 1986, Bridge waterways analysis model; research report: Federal Highway Administration Publication FHWARD-86-108, $112 \mathrm{p}$.

U.S. Geological Survey, 1963, New Ellenton SE, S.C., quadrangle: 7.5-minute series topographic map, scale 1:24,000.

1964, Girard NW, S.C., quadrangle: 7.5-minute series topographic map, scale $1: 24,000$. 1965a, New Ellenton SW, S.C., quadrangle: 7.5-minute series topographic map, scale $1: 24,000$.

1965b, Shell Bluff Landing, Ga.-S.C., quadrangle: 7.5-minute series topographic map, scale 1:24,000.

Zalants, M.G., 1990, Low-flow characteristics of natural streams in the Blue Ridge. Piedmont, and upper Coastal Plain physiographic provinces of South Carolina: U.S. Geological Survey Water-Resources Investigations Report 90-4188, $92 \mathrm{p}$. 


\title{
APPENDIX
}

\author{
List of Elevation Reference Marks
}


[ft, feet; USGS, U.S. Geological Survey; mi, mile; USC\&GS, U.S. Coastal and Geodetic Survey] (In this report, the words "right" and "left" refer to directions that would be reported by an observer facing downstream.)

\begin{tabular}{|c|c|c|}
\hline Benchmark & Location & $\begin{array}{l}\text { Elevation } \\
\text { at ove sea } \\
\text { level } \\
\text { (ft) }\end{array}$ \\
\hline FMB30 & $\begin{array}{l}\text { Chiseled square in the downstream left end of the Road A- } 12.2 \\
\text { bridge crossing Fourmile Branch; } 10,326 \mathrm{ft} \text { downstream from Road } \\
\text { A. Established by the USGS. }\end{array}$ & 112.49 \\
\hline FMB50 & $\begin{array}{l}\text { Chiseled square in the downstream left abutment headwall of the } \\
\text { CSX Railway bridge crossing Fourmile Branch, } 6,257 \mathrm{ft} \text { down- } \\
\text { stream from Road A. Established by the USGS. }\end{array}$ & 146.67 \\
\hline FMB70 & $\begin{array}{l}\text { Chiseled square in the upstream left abutment headwall of the } \\
\text { Road A bridge crossing Fourmile Branch. Established by the USGS. }\end{array}$ & 146.02 \\
\hline FMB 170 & $\begin{array}{l}\text { Chiseled square on the downstream left abutment headwall of the } \\
\text { Road C bridge crossing Fourmile Branch. Established by the USGS. }\end{array}$ & 202.68 \\
\hline R102 & $\begin{array}{l}\text { Brass tablet located } 3.15 \text { mi southwest of the junction of Road C and } \\
\text { Road 3, about } 0.4 \text { mi northeast of four } 6 \text { - } \mathrm{ft} \text { diameter concrete pipes } \\
\text { over Fourmile Branch, at the junction of the woods road leading } \\
\text { north, } 59 \mathrm{ft} \text { north of the center line of Road } 3,37 \mathrm{ft} \text { west of the center } \\
\text { line of the woods road, } 2 \mathrm{ft} \text { east of the metal witness post, } 1.5 \mathrm{ft} \\
\text { below the level of the highway. Established by the USC\&GS. }\end{array}$ & 200.154 \\
\hline U102 & $\begin{array}{l}\text { Brass tablet located at the junction of Roads } C \text { and } 5 \text {, set in the junc- } \\
\text { tion Y of Road } 5,80.5 \mathrm{ft} \text { southwest of the centerline of the southwest } \\
\text { two of four lanes of Road C north, } 77 \mathrm{ft} \text { southeast of the center line } \\
\text { of Road } 5,71 \mathrm{ft} \text { northwest of the centerline of the southeast leg of } \\
\text { the junction. Established by the USC\&GS. }\end{array}$ & 301.213 \\
\hline
\end{tabular}




\section{APPENDIX--List of Elevation Reference Marks--Continued}

[ft, feet; USGS, U.S. Geological Survey; mi, mile; USC\&GS, U.S. Coastal and Geodetic Survey]

(In this report, the words "right" and "left" refer to directions that would be reported by an observer facing downstream.)

\section{Benchmark}

Location

Elevation

above sea

level

(ft)

$\mathrm{M} 101$

Brass tablet located at crossing of CSX Railway and Road 3, 259

153.372

degrees north and across the track from mile post Number $438,33 \mathrm{ft}$

northeast of northeast rail, $49.5 \mathrm{ft}$ southeast of the centerline of the road, $60.5 \mathrm{ft}$ east of the center of the crossing. Established by the USC\&GS.

L101 Brass tablet located $0.6 \mathrm{mi}$ southeast along the CSX railway from

152.218 the Road 3 crossing, thence $0.15 \mathrm{mi}$ south on a spur track to Area D, at the crossing of Road A-12 (a black top road), the road passes between the main line track and the Area D, $114 \mathrm{ft}$ southeast of the southeast rail of the spur track, in the top of a concrete block $18 \mathrm{ft}$ wide by $27 \mathrm{ft}$ long by $1 \mathrm{ft}$ high, $188 \mathrm{ft}$ northeast of the center line of the road. Established by USC\&GS.

H101 Brass tablet located 4.75 miles northwest along CSX railway from

150.193 the railway station at Robbins, at the crossing of Road A-13 and CSX Railway, $24 \mathrm{ft}$ northeast of the northeast rail, $27 \mathrm{ft}$ southwest of the center line of the road, $69 \mathrm{ft}$ north of the center of the crossing, and $1 \mathrm{ft}$ southeast of a metal witness post. Established by the USC\&GS.

X102 Brass tablet located 1.35 mi north on Road 4 from junction of Road 249.350 $\mathrm{C}$ and Road 4, thence $0.9 \mathrm{mi}$ northwest on M Line U.S. Government Railway track, about $0.1 \mathrm{mi}$ northwest of milepost No. $12,85 \mathrm{ft}$ southwest from the southwest rail of track, $2 \mathrm{ft}$ southeast of the metal witness post, $1 \mathrm{ft}$ above the level of the track. Established by the USC\&GS. 